\section{Educating the data user: the role of bibliographic instruction}

by Kristin $\mathrm{McDonough}^{1}$

Baruch College, City University of New York

The program of credit courses in research methods and materials offered by the Library Instruction Division at Baruch College, CUNY, has been in existence since the early 1970's. With the exponential growth of information and the advancement of technology the courses have shifted dramatically from a practical "how to use the library" approach to a more conceptually based one that integrates process and product, tools and techniques, traditional print and electronic information sources. What were pioneered as library research courses two decades ago have come to bear the titles "Information Research in Business" and "Information Research in the Social Sciences and the Humanities", testimony to the fact that the site of research is now just as often an online laboratory or a personal computer in the office or home as a library.

\footnotetext{
${ }^{1}$ Presented at the International Association for Social Science Information Service and Technology (1ASSIST) Conference held in Washington, D.C., May 26-29, 1988
}

Of course, research involves much more than just a choice of site or form/media in which a body of disciplinary evidence or a synthesis of opinion, or string of raw numbers is stored. As research methods have evolved and changed, so has the content of these basic courses over the years. One of the most dramatic changes in the substantive content of the courses has been the increase in emphasis on access to, evaluation, and use of public data. Our team of six bibliographic instruction librarians has a special commitment to alerting students to potential sources of data because of the nature of the institution in which we teach. Baruch College is, arguably, the largest business school in the world. As such, it attracts students who are, or are quickly trying to become, quantitatively oriented, and offers business and social science courses that are, in the main, quantitatively based. By junior year a student can reasonably expect in one semester to be working on a demographic analysis for a market plan, an econometric projection for a finance course, and the comparison of a fictitious company's data with that of a national sample for an industrial management class.

What is perhaps surprising is that emphasis more often is on the manipulation and application of numbers, using increasingly sophisticated statistical and spreadsheet software, than on identification and retrieval of the sources of these figures. By and large, students are provided with the numbers that they are expected to "crunch." Our goal in the information research courses is to go a step further and tie the identification of authoritative sources of data to the secondary data analysis. We teach students how to identify and recognize potential sources of data from ever-growing core of government, institutional, corporate and private generators of data on both domestic and international levels because we are loathe to make them dependant on data derived from out-of-date textbooks and recycled classroom lectures. 
If our courses as now constituted succeed in the important task of convincing students of the relative availability of published data relevant to their particular needs, it is because we have made a conscious effort to integrate this notion into the fabric of the courses. This was. unfortunately, not always so, at least not for those sections of the courses taught by a humanities-oriented, numbers-shy librarian such as myself. In fact it is only within the past six or seven semesters that I have stopped treating statistics as a separate entity to be introduced toward the middle of the semester and confined to a fairly cursory treatment of standard sources, such as the specialized statistical indexes.

There are several reasons for my former approach to statistics as a self contained unit broached halfway into a course. The first is simply that the material on statistical sources forms chapter 11 in each of the two in-house textbooks that we use in these courses: Access Information: Research in the Social Sciences and the Humanities, and Access Information: Research in Business. The position of this chapter, following a chapter on government documents, meant that an instructor following the chronology of the text waited to focus on statistical sources until the students had wrestled with government documents - that bibliographically unwieldy type of material daunting even to the most experienced of librarians. The reasoning behind this order of presentation seemed to be that since so many of the important statistical series are, in fact, government publications with complex corporate authorship and involved series added entries, it was best to deal with these later in the semester when the students would be more knowledgable. linking statistical sources with government documents not only reinforced the notion that statistics could be complicated to identify - as anyone who has searched under 'United States. Bureau of the Census' as author can attest but, in a non-depository library like ours, difficult to actually locate.
Another reason for this artifical approach toward teaching public data sources was the use of the search strategy as a conceptual framework upon which to structure the presentation of instructional material and the completion of assignments. A search strategy is a suggested sequence of steps to be followed in conducting research on almost any subject. The order is, of course, approximate, and the object is to dispel the notion that relevant knowledge and information on a subject are acquired serendipitously rather than through a orderly process using standard bibliographic tools. Using this approach, for example, librarians have students choose a topic of their choice and then introduce them, first, to the notion of background reading, sthen to the definition of terms using a thesarus, thirdly to the identification of a bibliography of previous research, fourthly to books using the catalog, fifthly to periodicals for current information, and finally, the icing on the cake, to RECENT STATISTICS. One was lucky to have guided the students this far through a search strategy by the midterm point!

Below are selected examples of the approach adopted over the past few years in an attempt to underscore the centrality and virtual omnipresence of quantitative evidence in the sort of contemporary social science research in which students are expected to engage or with which, at minimum, they are expected to be familiar. Though I continue to use a modified search strategy framework, my goal is to stress the fact that there are a number of ways to identify and access significant collections of published data. The focus of these examples is child day care, a timely and interesting topic for our largely working class students at Baruch.

Very early in the semester students are taught to immerse themselves in a subject as they start their research. This initial immersion is referred to as background reading and yields a definition and condensed history of the subject, an overview of the major issues involved, as well 
as the identification of major associations and researchers who have contributed to the formation of the body knowledge in the field.

A specialized encyclopedia, such as in this case the Encyclopedia of Social Work, is often an ideal source of background reading. It features an expanded definition of the modalities of child care, with references to both individual and teams of researchers, as well as government agencies which have gathered data relating to "neighborhood care for several million families" (illus. 1). An additional point about the time lag inherent in data collection and analyis can be made by noting how relatively dated are the references in, for example, the latest 1987 edition of an authoritative reference book. (illus. 1)

In explaining the parenthetical citation form used in the encyclopedia, it is necessary to refer to the list of references appended at the end of each article. Focusing on the organizations represented in the entries is an ideal way to underscore the number and variety of groups involved in data collecting. (illus. 2) Profiles of these groups in the Encyclopedia of Asociations indicate those which have data gathering central to their mission. (illus.3)

Guides to the literature or research guides are a generic family of library tools that students are encouraged to use early in the semester. It seems relevant to introduce the latest edition of Wasserman's Statistics Sources at the same time as Webb's Sources of Information in the Social Sciences and Friedes' Literature and Bibliography of the Social Sciences. As the illustration (illus. 4) suggests, students should be alerted to the fact that to maximize retrieval of information, flexibility of approach is essential. Important series of statistics on day care can be found by looking either under "CHILD CARE ARRANGEMENTS" or under "CHILDREN MOTHERS WORKING." That many of the publications identified in this guide are available on magnetic tapes as well as in paper is a point made again and again.

This very question of research terminology is one best tackled right at the start of search strategy, with LC Subject Headings introduced as an example of a thesaurus. Its function is to provide an authority list of terms to be used in searching the catalog for books on a topic. One of the key points is that once the researcher determines the correct heading or search term, quantitative data on that same subject can be found by employing the standard subdivision - STATISTICS immediately following the heading, e.g. DAY CARE CENTERS -UNITED STATES --STATISTICS. (Illus. 5)

Another type of reference tool with which students should fairly quickly become familiar is the handbook. The Statistical Abstract of the United States is introduced as an example of the type of handbook that is a compilation of tables, as well as the first recourse a student has when confronted with the task of "finding statistics". But rather than emphasize only the technical features of this single volume wonder, with its tabular titles, headings and notes, contents tables and subject index, it is more effective to present this as a first step which offers a "snapshot" of the full range of statistical series available from various government agencies. In the illustration below (illus. 6), for example, the crucial part of the table is the source note which identifies a Current Population Report by series number. That these periodic census updates are relatively easy to find and are available in machine-readable form are points that can be made immediately and re-emphasized later in the course of reviewing the concept of series entries as one of the elements of the catalog. (illus. 7)

By this very early point in the semester, then, students have been shown that a key publication such as Current Population Reports can be located in a variety of ways, through references in a bibliographic guide (Statistics Sources), or 
those in a handbook (Statistical Abstract of the United States), or through the subject or series approach to the library's catalog. That there is more than one route in no way diminishes the key importance of American Statistics Index or the Statistical Reference Index, which are now routinely introduced along with other periodical indexes. The power of these relatively

sophisticated bibliographic tools and the level of detailed analysis they provide of statistical publications is impressed on the students. One effective way in which to start students thinking about the degree of complexity of a social issue such as day care is to have them simply scan the index volume of either $\underline{\text { ASI }}$ or SRI and note the various aspects of the subject on which data are generated and collected for subsequent analysis and policy implementation. This pair of bibliographic tools are no longer only viewed as access tools alone but also as a record or mirror of the perspectives from which day care can be viewed: a service to working mothers, a fast growing service industry, a tax benefit to individuals and corporations, an employee benefit, a unit in the health and nutrition delivery system and so on. (Illus. 9)

One reason why it is important to familiarize students with a number of other indexes that can lead to statistical series is that the wealth of material identified by $\underline{\text { ASI }}$ or SRI, either online or in print, can be overwhelming and ultimately disappointing, especially to students using a non-depository library of moderate size which may not subscribe to all the publications indexed. Other indexes that are profitably introduced as adjuncts to, if not substitutes for, the above are Monthly Catalog of the United States (illus. 10) and the PAIS Bulletin (illus. 11). The latter identifies quantitative studies in two ways : with the subdivision "Statistics", or by means of a note in the citation indicating that the material contains graphs, tables, charts. Each of these indexes generally employs subject terms identical to LC Subject Headings, with which, by this time, the students feel familiar.
References to public data can also be used effectively when the class discusses the protocol of documentation, which is a concept that undergraduates often find difficult to grasp. "What kind of facts do I have to cite?" is one of the most frequently asked questions, to which for years I had been responding, "Any opinion not your own, controversial ideas, facts that are not generally known." Since adding to that not very helpful list "figures or data that are subject to change" I have begun to sense that at least a few of the students now comprehend. They are beginning to understand that a statement such as "Albany is the capital of New York State" is both generally known and relatively stable but that a reference to the population of New York state should be documented since demographic figures change. In fact, as the students now realize, reference to statistics that are woefully in error is one of the surest signs that the sources on which a paper is based are either out-of-date or unreliable.

Then, too, even the most reliable and authoritative of sources is never entirely bias-free, and is certainly subject to misinterpretation, an observation that surfaces continually in class discussions on the importance of evaluating material. In response to an assignment to identify at least one publication or report the data in which have susequently been questioned, several students located accounts in the popular press or scholarly literature about surveys whose results had been either misrepresented or misinterpreted. A New York Times article reported an assertion by one researcher that the number of latchkey children in the U.S. is far greater than suspected, since the estimate of their numbers has largely been based on the self-reported responses of the parents. Many working couples who are surveyed may not admit that their young children are left alone at home while they are at work. A union newspaper published by the AFT contained an editorial repudiating the results of an NIE report on school crime on the grounds that the 
national survey had made virtually no distinction in the category "incidents of crime" between pranks, minor vandalism and armed assualts on teachers! As each student reported on the assignment orally to the class, it became clear that for the majority of students, this exercise really made the notion of data come alive.

Undoubtediy, the fact that Bliss Siman, the ICPSR coordinator for all units of the City University of New York, is a dyanmic member of our teaching team has contributed to our determination to make awareness of potential sources and uses of survey, census, and time-series data a vital part of our credit courses. For several semesters she has been presenting sessions on the secondary analysis of data to all sections of the social sciences and business information research courses, using an approach that she describes elsewhere in this issue. The prime motive for the emphasis we place on the interdependence between data identification, retrieval and evaluation on the one hand and manipulation on the other, is to give the students the skills necessary to locate sources of authoritative data.

There is yet another impetus behind our thrust toward familiarizing even our beginning. non-specialist students with sources of available data. We want, over the course of the undergraduate's career, to turn the student into a discerning and demanding consumer who will incorporate use of data into subsequent business and professional life. Without a developed group of educated and expectant users coming out of our colleges, universities and professional schools, who will join with librarians and scholars to protest, for example, the Bureau of the Census? intent to make certain of their series available in electronic form only? In the future, when dollar values are put on information and access becomes a matter of economics and political will, we hope that our efforts in the classroom will have had some effect. ㅁ

\section{Bibliography}

American statistics index. Washington, DC: Congressional Information Service, 1974 -.

Encyclopedia of associations. Detroit, Mich.: Gale Research Co., 1979 - .

Encyclopedia of social work. Washington, DC: National Association of Social Workers, 1974.

Friedes, Theima. Literature and bibliographv of the social sciences. Los Angeles, Ca.: Melville Pub. Co., 1973.

PAIS bulletin. New York, NY: Public Affairs Information Service, 1986 -.

Sources of information in the social sciences: a guide to the literature. 3rd. ed. Chicago, I1: American Library Association, 1986.

Statistical reference index. Bethesda, Md: Congressional Information Service, 1980 -.

Statistics sources. Detroit, Mich.: Gale Research Co., 1983.

United States. Bureau of the Census Current population reports. Washington, DC: U.S. Government Printing Office, 1948 -.

United States. Bureau of the Census Statistical abstract of the United States. Washington, DC: U.S. Government Printing Office, -latest.

United States. Library of Congress. Subject Cataloging Division Librarv of Congress subject headings. Washington, DC: Library of Congress, 1986. 


\section{Illustration 1}

Encyclopedia of Social Work. 18th Edition. Edited by Anne Minahan. New York: National Association of Social Workers, 1987.

older brothers and sisters, grandmothers, other kin, and householders to the extent possible, or even on the children themselves (Werner, 1984).

Increasingly, however, families are turning to care outside the home. It is estimated that this was the case by 1980 for about half of all children under 6 (U.S. Bureau of the Census, 1982). Smaller families and in. creased rates of maternal employment have gone hand in hand, and most families using out-of-home care are purchasing care for one child (Emlen, 1974, 1982; Hayghe, 1984).

Family Day Care. The care of children in a relatives home is less common than th used to be (U.S. Bureau of the Census, 1982). Day care is more likely to be nearby whtha neighbor. Family day care is provided by women who are not in the labor force, who have child care responsibilities of their own (usually involving larger families), and whose experience and motivations are suited to providing a child care service, typically involving three or four children-less than the limits imposed by regulation. Family day care is the predominant resource used outside the home for infants and toddlers. It is also a major resource for school-age children. Care in family homes affords fexibility in the ages of children accommodated and in the hours that care is provided. Concern has been raised about the use of family day care in deterio. rated neighborhoods, about the isolation of caregivers from social support and training, and about their inaccessibility to regulation or to I \& R programs. Family day care persists, howeyer, as a viable system of nëighborhood care for several mittion-families (Collins \& Watson, 1976; Emlen, 1974; Emlen \& Koren, 1984; Fosburg et al., 1981; Werner, 1984).

Cenfer Care. Athough nonprofit day care centers continue to provide a significant amount of subsidized care for lower-income
500 percent in 5 years (Kinder-Care, 1983) and has the largest market share of the center care business. The second-largest chain, La Petite Academy, has over 400 programs in 24 states, and Children's World serves more than 20,000 children in 160 centers (Fried. man, 1985). These chains bave been profitable, in part by achieving efficiencies from large numbers of children per center and minimum labor costs, as well as by marketing their discount programs to employers.

Treatment In Day Core Settings. In any community, child care is recognized as occupying an important, though often neglected, position on a continuum of specialized services to families at risk of dissolution. Whether for mental health or child welfare, child care is one of the least restrictive services that can be supportive of family functioning and of a child's treatment program. Child care services play a part in the "reasonable effort" required as alternatives to placement in foster care or residential treatment facitities (Adoption Assistance and Child Welfare Act of 1980, P.L. 96-272).

Employoe Asslstonce. Of wider scope, however, are two kinds of services to families to help them cope with their child care responsibilities. One is the employee assistance program (EAP), which began as a corporate approach to problems related to alcoholism and has been broadened to address the individualized child care needs of emplojees. Employee assistance programs have expanded in scope as more attention has been paid to how employees manage child care, how it affects their work, and how company policies, in turn, facilitate or adversely affect the ability of employees to combine working with family responsibilities. The flexibility of policies concerning sick leave, maternity and paternity leave, flexible work hours, and absenteeism are being modified by companies, 
Mlustration 2

Encyclopedia of Social Work. 18th Edition.

Services. Phase I Results. Cambridge, Mass.: Author.

Beer, E. (1957). Working Mothers and the Day Nursery. New York: Whiteside.

Blank, H. (1985). Fact Sheet. Washington, D.C.: Children's Defense Fund.

Brookings Institution. (1972). Setting National Priorities: The 1973 Budget. Washington, D.C.: Author.

Bureau of National Affairs. (1984). Employers and Child Care: Development of a New Employee Benefit. Washington, D.C.: Author.

Burud, S., Aschbacher, P., \& McCroskey, J. (1984). Employer-Supported Child Care: Investing in Human Resources. Dover, Mass.: Auburn House.

Campbell, N. (1985). Analysis of Internal Revenue Service Data. Washington, D.C.: National Women's Law Center.

Catalyst. (1983). Child Care Infurmation Service: An Option for Employer-Support of Child Care. New York: Author.

Children's Defense Fund. (1982). Employed Parents and Their Children: A Data Book. Washington, D.C.: Author.

City Club of Portland. (1985). Survey of EmployeeSponsored Child Care Options. Portland, Oregon: Author.

Class, N., \& English, J. (1985). “Formulating Valid Standards For Licensing." Public Welfare, $43(3), 31-35$.

Clinton, L. (1985). "Guess Who Stays Home with a Sick Child?" Working Wother, 8(10), 55-61. Coelen, C., Glantz, F., \& Calore, D. (1978). Day on the Wo

Portland, C Emlen, A., et al porate Finc Service. P University Fasciano, N. Sneezles $t$. Child Care Mother, 8 Fosburg, S., et United Sta No. [OHD U.S. Govt Friednan, D. ( Care: Hor Expectati (10), $1-6$.

Frieman, D. ( ance for ( Board.

Galinsky, E. ( Policies." (Eds.), Si Boston: 1 Grubb, W. N

Frontiers and Parer Lazerson Americar. New Yor Hayghe, $H$. Record 1 Review, . Hayghe, H. (I 
Illustration 3

Encyclopedia of Associations. 22nd Edition. Detroit : Gale, 1988.

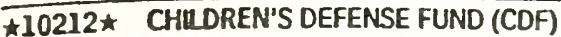

\section{C St., N.W.}

Washington, DC 20001

Phone: (202) 628-8787

Marian Wright Edelman, Pres.

Founded: 1973. Staff: 60 . Budget: $\$ 4,000,000$. Provides systematic, longrange advocacy on behalf of the nation's children. Engages in research, public education, monitoring of federal agencies, litigation, legislative drafting and testimony, assistance to state and local groups, and community organizing in areas of child welfare, child health, adolescent pregnancy prevention, child care and development, family services, and child mental health. Works with individuals and groups to change policies and practices resulting in neglect or maltreatment of millions of children. Advocates: access to existing programs and services; creation of new programs and services where necessary; enforcement of civil rights laws; program accountability; strong parent and community role in decision-making; adequate funding foressential programs for children. Maintains speakers' bureau; compiles statistics. Publications: (1) CDF Reports (newsletter), monthly; (2) Adoleseef-Pregnancy Prevention Clearinghouse Reports, bimonthly; also publishes series of books and handbooks on issues affecting children. Formerty: (1978) Children's Defense Fund of the Washington Research Project. Convention/Meeting: annual conference.

\section{$\star 10213 \star$ CHILDREN'S RIGHTS GROUP (CRG) 693 Mission St. \\ San Francisco, CA 94105}

Phone: (415) 495-7283

Vicki Strang, Deputy Dir.

Founded: 1974. Staff: 33. Organization working primarity in the western and southwestern U.S. to help communities and parents utilize, upgrade, and expand available services for children. Offers workshops, training seminars, and technical assistance to parents who seek to bring federally funded child nutrition programs into their community. Makes a special effort to aid organizations that work with migrant farmworkers' families. Sponsors Project Save, an energy conservation/youth employment program providing free home weatherization for low-income households in Daly City and San Francisco, CA. Conducts analyses of issues and legislation that affect children's services, particularly tax limitation proposals such as Califomia's Proposition 13. Lobbies for Fair Housing for Children ordinances (making it illegal for landlords to refuse rental to families with children) in California. Operates an employerrelated child care project to promote child care services for employees of major Bay Area employers. Compiles data on federal food program participation. Focuses research on children's services including heatth, nutrition, and child care. Publications: Community Services Bulletin, monthly; also publishes $\star 10217$

P.0. Box

Washingt

Founded.

ports sta

informati

Children's

$\star 10218$,

$3955 \mathrm{Crá}$

P.0. Box:

Colorado

Founded:

Offers $m$

vides for

nancial st

children's

special $c$ :

sorship (1

children :

(assists (

and other

(assists n

lications:

chures. F

passion. (

$\star 10219$ \#

c/o Coun

1920 Ass

Reston, V

Founded:

supportivi

impaired

ducts ser

Environm!

Scholarshi

Formerly:

Children;

Hospitaliz,

for Excep 


\section{Illustration 4}

Statistics Sources. 10th Edition. Edited by Paul Wasserman. Detroit: Gale, 1986.

\section{STATISTICS SOL'RCES, Eleventh Edition - 1988}

CHICKENS - SE POULTRY

CHILD ABUSE

American Humane Association, 9725 East Hampden, Denver, Colorado 80231: annual report, "National Analysis of Official Child Neglect and Abuse Reporting :

\section{CHILd care arrangements}

U.S. Department of Commerce, Bureau of the Census, Suitland, Maryland 20233; "Current Population Reports"

\section{CHILD SUPPORT PAYMENTS AND ALIMONY}

U.S. Department of Commerce, Bureau of the Census, Suitland, Maryland 20233; "Current Population Reports"

CHILDREN - See also POPULATION and VITAL STATISTICS

\section{CHILDREN - AID - SOCIAL WELFARE PROGRAMS}

U.S. Department of Health and Human Services, Social Security Adminiatration, 6401 Security Boulevard, Baltimore, Maryland 2123S; monthly report "Social Security Bulletin,"

"Annual Statistical Supplement," monthly report, "Public Assistance Statistics," and unpublished data.

U.S Library of Congress, 10 First Street, SE, Washington, D.C. 20540; "Cash and Non-Cash Benefits for Persons With Limited Income Eligibility Rules, Recipient and Expenditure Data," September 1985

CHILDREN - ALIENS

U.S. Department of Justice, Immigration and Naturalization Service, 425 I Streel, NW, Washington, D.C 20536; "Statistical Yearbook," annual, and releases

\section{CHILDREN - ATTENDING SCHOOL}

U S Department of Commerce, Bureau of the Cengus, Suitland, Maryland 20233; "Current Population Reports," and unpublished data.

U.S. Department of Education, 400 Maryland Avenue, SW, Washington, D.C. 20202; "Biennial Survey of Education in the United States," Chapter on Statistical Summary of Education, annual reports, "Digest of Education Statistics," and "Statistics of Public Elementary and Secondary Schuols System," "Projections of Education Statistics," "Estimates of School Statistice," "Rankings of the States," and unpublished data

CHILDREN - DAYS LOST FROM SCHOOL

U.S. Department of Health and Human Services, Public Health Setvice, 200 Independence Avenue, SW, Washington, D C 20201, "Vital and Health Statistics," and unpublished data

CIIILDREN - FAMILIES WITH
CHILDREN - IMMUNIZED AGAINST DISEASE

US Department of Health and Human Services, Center for Disease Control, 1600 Clifton Road, NE, Atlanta, Georgis 30333, annual report, "United States Immunization Survey"

\section{CHILDREN - JUVENILE DELINQUENCY}

U.S. Department of Justice, Bureau of Prisons, 320 First Street, NW, Washington, D C. 20534, "Statistical Report "

U.S. Department of Justice, Law Enforcement Assistance Administration, 633 Indiana Avenue, NW, Washington, D C. 20531, "Children in Custody Advance Report on the 1982 Census of Public Juvenile Facilities," and "Children in Custody Advance Report on the 1982 Census of Private Juvenile Facilities -

\section{CHILDREN - MOTHERS WORKING}

U.S. Department of Commerce, Bureau of the Census, Suttland, Maryland 20233; "Current Population Reports," and unpublished data

US Department of Labor, Bureau of Labor Statistics, 200 Constitution Avenue, NW, Washington, D C 20212. "Special Labor Force Reports," and unpublished data.

\section{CHILDREN - NUMBER - PER DIVORCE DECREE}

U.S. Department of Health and Human Services, Public Health Service, 200 independence Avenue, SW, Washington, D C. 20201; annual report, "Vital Ststistics of the United States," "Monthly Vit al Statistica Reports," and unpublished data

CHILDREN - OLD-AGE, SURVIVORS, DISABILITY, AND HEALTH INSURANCE BENEFITS

US Department of Health and Human Services, Social Security Administration, $6 \mathbf{4 0 1}$ Security Boulevard, Baltimore. Maryland 21235; "Annual Statistical Supplement to the Social Security Bulletin," and unpublished data.

\section{CHILDREN - ORPHANS}

U.S. Department of Health and Human Services, Sicial Security Administration, 6401 Security Boulevard, Baltmore, Maryland 20235, unpublished data

CHILDREN - PARTICIPATING - IN SCHOOL LUNCH PROGRAMS

U.S. Department of Agriculture, Food and Consumer Setvices, Fourteenth Street and Independence Avenue, SW, Washington, D.C. 20250; annual report, "Agricultural Statistics," and unpublished data.

CHILDREN - UNDER EIGHTEEN - BY PRESENCE OF PARENTS 
Illustration 5

CUNY Library. Card catalogue.

DAY CARE CENTERS--UNITED STATESSIA I I I I CS.

Ref

BA

203

A218

no. 149

Bruno, Rosalind R.

After-achool care of school-age

children: December 1984/ by Rosalind R. Eruno. - Washington, D.C.: D.S. Dept. of Commerce, Bureau of the Census : [U.S.G.P.O., distributor] ; 1987 . $1 \mathrm{v}, 27 \mathrm{pe:}$ : 1 form; $28 \mathrm{~cm}$. -

( Current population reports, gpecial

studieg series P-23; no. 149)

Shlpplng list no: : 87-64-P.

"Isaued January 1987."

Includes bibliographical references.

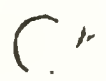

NNBBC 29 SEP $87 \quad 15238845 \quad$ VVBRAC SEE NEXT CRD 
Illustration 6

U.S. Department of Commerce. Statistical Abstract of the U.S.. 108th Ed. Washington, D.C., 1988.

No. 596. Child Care Arrangements of Childaen Unoer 15 of Employed Motheas, ay age of CHIL AND EMPloyment Status of MOthef: 1984-1985

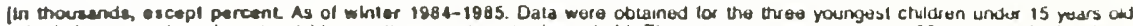

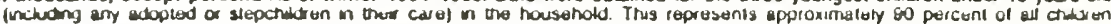

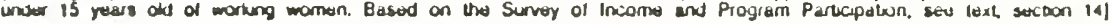

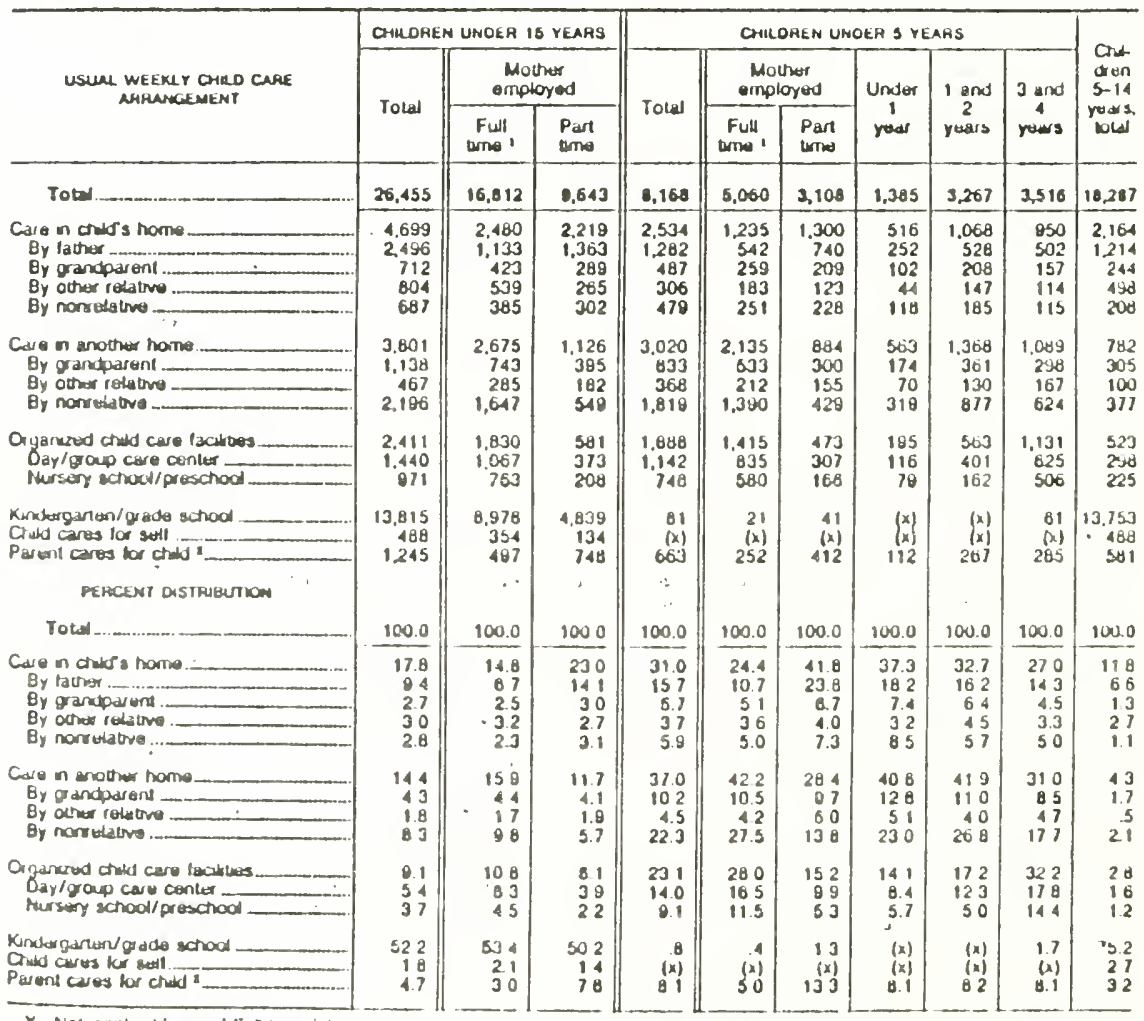

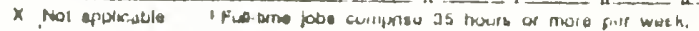

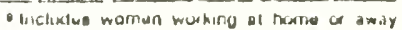




\section{Illustration 7}

CUNY Library. Card catalogue.

$\operatorname{Ref}$

HB

820

E36
Current population reporta. Serles P70, Household economic studies. No. 1- (3rd quarter 1983)-no.6 (4th quarter 1984); No. 7- . Waghington, D.C.: U.S. Dept. of Commerce, Bureau of the Census: For sale by the Supt. of Docs., U.S. G.P.O., 1884$\nabla . ; 28 \mathrm{~cm}$.

Quarterly.

"Average monthly data from the Survey of income and program participation." Report nos. 1-6 have title: Economic characterlstics of households in the United States; Report nos.7- have dist inctive titlos.

$$
\text { Report no. }
$$
$P-70-83-4$.

[2] has designation:

ISSN $0886-5 \cup 698=$ Current 11567017 VVBRdC SEB NEXT CRD 


\section{Illustration 8}

\section{American Statistical Index. 1987 Ed. Washington, D.C., Congressional Information Services.}

TABLES:

[Tables 1.6 show data for Doc 1984.

Caretakers of children include pareats, adult siblings, other adult relatives, unrelated adults, nonadults, and self-care.

Data by type of household are shown for all, married couple; and fecnale-headed households.]

\section{CHILDREN}

[Tables ahow number of children aged 5.13 years old enrolled in school.]

1-2. [By] after-school caretaker of children, age of child, type of bousehold, labor force status of wother, and race. (p. 7-12)

3. [By] after-school care [caretaker] of children whose mothers work full time by occupation and education of mother, family income, and race. (p. 13)

4. [By] hours of care for children who regularly spend time not under parents' supervision, type of caretaker, and period of day. (p. 15) HOUSEHOLOS

[Tables show number of housebolds with children aged 5-13 years old enrolled in school]

5. By whether fully cared for by parents after school and whether any child was regularly not in adult care, by type of household, labor force status and education of female houscholder, and family income. (p. 16)

6. By number of children and wbether any child was not in adult case after school, by labor force status of femsic houscholder and race. (p. 17)

\section{TRENDS}

7. [Number of children by] after-school child care arrangements [caretaker] for children $5-13$ years old [and] labor force status of mother: OCL 1974 and [Dec.] 1984. (p. 17) described below. Part A is described in AS1 1986 Annual (or 1986 Monthly Suppleınent 11) under this number. The remaining 4 parts have not yet been issued.

A similar report was issued for the 1970 census (see ASI Retrospective Edition and Ist-3rd Annual Supplements under 2557-1).

2555-2.2: Part B. Chapter 4. Census Promotion Program. Chapter 5. Fiold Enumera. tion

[Dec. 1986. 16+103 p. PHC80-R2-B. Price not given. ASI/MF/4]

Contents:

Chapter 4. Includes narrative discussion of census promotion program objectives and activities; supporting organizations and program participation; facsimile advertisements and other promotional materials; and program evaluation. (p. 4.1-4.16)

Chapter 5. Includes narrative discussion of ccosus field operations, organizalion structure, logisties, personel and training, and mailing and interviewing procedures; lists of district offices and publicand field-use forms; facsimile reporting forms; stafling calendars; and 6 methotological tables. (p. 5.1-5.103)

2555-3.3: Part C. Chaptar 7. Sampling and Estimusion. Chapter 12. Population and Housing Content Itams

[Dec. 1986. $9+75$ p. PHC80-R2-C. Price not given. ASI/MF/3]

Contents:

Chapter 7. Includes aarrative discussion of sample design and features, estimation procedures, and sampling variability and errors; and list of references. (p. 7.1-7.9)

Chapter 12. Includes narrative discussion of each population and housing question. naire item, its purpose and history, user instructions, and computer editung and processing specifications; facsimile survey forms; computer edit sequeace; and lists of instructional and classification codes. (p. 12.1-12.75) 


\section{Illustration 9}

American Statistical Index, 1987 Ed. Washington, D.C., Congressional Information Services.

Child day care

AFDC eligibility and payment errors, by type and State, 2nd half FY84, semiannual rpt, 4692-1

AFDC recipients demographic and financial characteristics, by State, FY83, annual rpt, 4694-1

Employer-sponsored child day care, finances and operations of Federal program by agency, with data for selected private firms, 1985, GAO rpt, 26119-104

Employment in selected high- and low-growth occupations, by sex and race, 1980 and projected to $1990,9248-19$

Expenditures for child care by family composition, and working women's child care arrangements by type and payment source, 1981-82, article, 1702-1.610

Food aid programs of USDA, costs and participation by program, FY69-85, annual rpt, 1364-9

Food aid programs of USDA, participants and costs by program, region, and State, monthly rpt, 1362-14

Food service establishments and sales, by establishment type, 1977 and 1984, annual rpt, 1544-22.4

Handicapped children, by household composition and other characteristics, arrangement for care, and effects on family, 1981, 4948-5.2

Health screening at child day care centers, costs and accuracy of diagnoses, local area study, 1986 article, 4042-3.614

Hepatitis cases by infection source, age, sex, race, and State, and deaths, by strain, 1984 and trends from 1966, 4205-2

Income tax returns of individuals, by filing status, tax item, and income level, 1985, annual article, 8302-2.618

Income tax returns of individuals, detailed data, 1983, annual rpt, 8304-2

Labor supply, demand, turnover, and training by source, by detailed occupation, 1984 and projected to 1995 , biennial rpt, 6744-3

Occupational Outlook Handbook, 1986-87, see also Youth employment

Child support and alimony

AFDC eligibility and payment errors, by type and State, 2nd half FY84, semiannual rpt, 4692-1

AFDC State admin agencies performance measures, caseloads, payments, and costs, by State, FY83-84, annual rpt, 4694-2

Beneficiaries of noncash public and employer-based transfer programs, by income source and socioeconomic characteristics, 1984, annual Current Population Rpt, 2546-6.46

Child Support Enforcement Program financial and operating data, FY81-85, annual rpt, 4004-16

Collection of child support, States using selected methods including wage garnishment, various dates 1986, GAO rpt, 26121-119

Fed Govt spending in States, by type, program, agency, and State, FY85, annual rpt, $2464-2$

HHS financial aid, by program, recipient, State, and city, FY85, annual regional listings, $400+-3$

Income (household, family, and personal), by source, detailed characteristics and region, 1984, annual Current Population Rpt, 2546-6.48

Income tax retums of high income individuals with and without tax liability, income and tax iterns, 1983, article, $8302-2.614$

Income tax returns of individuals, by filing status, tax item, and income level, 1985, annual article, 8302-2.618

Income tax returns of individuals, detailed data, 1983, annual rpt, 8304-2

Income tax returns of individuals, selected income and tax items by income, preliminary 1984, annual article, 8302-2.617

Income tax returns of individuals, selected 


\section{Illustration 10}

Monthly Catalog of the U.S. 1987 ed. Washington, D.C., Government Printing Office.

v. : ill. ; $28 \mathrm{~cm}$

Annual

$\$ 1.00$ Title from caption. Previously classed: C 56.216:MA32 E Shipping list no: 86-771-P. 1985. Description based on: 1975. Oltem 142-A S/N 003-024-06472-3 @ GPO

1. Glassware - United States - Statistics-Periodicals. I. United States. Bureau of the Census. sn- 87042353 OCLC 03060022

\section{$87-7041$}

\section{3.158:MA 36 Q (85)-1}

Current industrial reports. MA36Q, Semiconductors, printed circuit boards, and other electronic components / U.S. Department of Commerce, Burean of the Census. Washington, D.C. : The Bureau : For sale by the Supt of Docs., U.S. G.P.O., 1986Supt of Docs., U.S. Govt. Print. Off., Washington, D.C. 20402 v. : ill. ; $28 \mathrm{~cm}$.

Annual

$\$ 1.00$

1985- Title from caption. Shipping list no.: 86-764P. 1985.

1. Semiconductors - Statistics - Periodicals. 2. Solid state electronics - Statistics - Periodicals. I. United States. Burean of the Census. PAR 86-642605 OCLC 14353189

\section{$87-7042$}

\section{3.164:455/985/ .1}

U.S. exports. World area and country by Schedule E commodity groupirgs. Washington, D.C. : U.S. Dept. of Commerce, Burean of the Census : For sale by the Supt. of Dacs., U.S. G.P.O., 1983- Supt. of Docs., U.S. Govt. Print. Off., Washington, DC 20402

v. ; $28 \mathrm{~cm}$.
Annual
$\$ 31.00$

1982- "FT 455." 1985 Dec. and annual, v. 1. Issued in 2 parts, 1982- Vols. for 1982- distributed to depository libraries in microfiche. Item 144A.9 (microfiche) S/N 003-02406510-0@ GPO ISSN 0741-8310 Continues: U.S. exports. World area by commodity groupings ISSN 0360-2249

1. Commercial products - United States - Statistics - Periodicals. 2. Commercial products - United States-Classificstion-Periodicals. 3. United States-Commerce-Statistics-Periodicals. 1. United States. Bureau of the Census. HF105.B73d 83-647834 382/.6/0973/19 OCLC 10092103

87.7043

Bruno, Rosalind R.

\section{3.186:P-23/149}

After-school care of school-age children : December 1984 / by Rosalind R. Bruno. - Washington, D.C. : U.S. Dept. of Commerce, Bureau of the Census : [U.S. G.P.O., distributor] ; 1987.

Page 28
Annual

$\$ 6.50$

Began with 1964/65. Previously classed: C 3. ping list no.: 87-77-P. 1984-85. Description basec Earlier v. issued as part of: City finances. Oltem 003-024-06232-1 @GPO 1SSN 0082-9439

1. Municipal finance-United States - Statist cals. 2. Local finance-United States - Statisti cals. I. United States. Bureau of the Census. Kt government finances II. Series: Government fina 4. HJ9011.A4b 74-648912//r81 336.73 OCLC

87.7045

\section{C $3.204 / 3.984$}

County business patterns, United States. Washington Dept of Commerce, Bureau of the Census : Fol Snpt. of Docs., U.S. G.P.O., Supt. of Docs., U.S. Off., Washington, D.C. 20402

v. : ill ; $28 \mathrm{~cm}$.

Annual

$\$ 5.50$

Began with 1973. Previously classed: C 3.204: no: 86-778-P. "CBP-84-1." 1984. Description 1978. OItem 133-A-52 S/N 003-024-06376-0 @ tinues in part: County business patterns, U.S. summ

1. United States - Industries - Periodicals. 1. Bureau of the Census. sn- 87042346 OCLC 0753'

$87-7046$

\section{3.205/3:WP-85}

World population profile. Washington, D.C. : U.S. I merce, Bureau of the Census : For sale by the St U.S. G.P.O., 1986- Supt. of Docs, U.S. Govt Washington, D.C. 20402

v. : col. ill., col. maps ; $28 \mathrm{~cm}$.

$\$ 4.25$

1985. Shipping list no.: 86-990-P. "W) Olem 146-F S/N 003-024-06218-6 @ GPC World population ISSN 0099-1139

1. Population - Statistics - Periodicals. 1. U Bureay of the Census. sn-87042039 OCLC 15207

\subsection{7}

\section{C $3.215 / 16982$}

Current housing reports. Series H-171, Annual hot supplementary reports. No. 1. Summary of housing tics for selected metropolitan areas. Washington, Dept. of Commerce, Bureau of the Census : For sa Services Division, Customer Services (Publications the Census, Data User Services Division, Custor (Publications), Bureau of the Census, Washington, v. : ill., maps, form ; $28 \mathrm{~cm}$.

Annual 
PAIS Bulletin. 1987. New York: Public Affairs Information Service.

tain prospects for ISDN: a Spanish :ommunications Policy 10:313-24 D

ces digital network.

Senegal needs informatics skills. table a snd Communications Rept 9:13-14

computers, telecommunications, and

i. Advanced information and echnologies: challenges and reconomics 22:79-84 Mr/Ap '87

society, the economy, and ions.

e. Com. on Public Works and asibility of allowing fiber optic cable e system: joint hearing, April 15. jubcommitiec on Economic the Subcommittee on Surface 7 iv $+227 p$ il table diags charts maps ess.) ([Pubn. no.] 99-63) (SD cat. no. 3) $\mathrm{pa} \longrightarrow$ Supt Docs

e. Com. on the Judiciary. Subcom. on rites, and the Admin. of Justice. unications Privacy Act: hearings, 35-March 5, 1986, on H.R. 3378. '86 99th Cong., 2d sess.) (Serial no. 50)

\section{:ernational aspects}

Sast data transfer: the German Transnational Dats and

Rept 9:11-14 Ag '86

1 conceptual framework for the insborder data fluws. Info Society

:e flow of information, national lependent development.

tde in data services: the international tts Telecommunications Policy

findings in his forthcoming book, sactions in services: the politics of lows."

$\checkmark$ Republic of Germany. table CTC inal Corps) Reporter p $14.15+$

\section{Regulation}

Mellors, Colin and David Pollits. Policing the communications revolution: a case-study of data protection legislation. West Eur Politics 9:195-2110 '86

Role of the OECD and the Council of Europe: national legislation.

\section{Social aspects}

Case, Donald and Everett Rogers. The adoption and social impacts of information technology in U.S. agriculture. bibl Info Sociesy 5:57.66 00 2 '87

Case study of an experiment in which 200 Kentucky farmers were given "green thumb boxes," videotex devices providing market, weather, and technological information through their television sets, 1980-81; conference paper.

\section{DAY CARE CENTERS}

Child care services in Singapore, 1981-1986. table charts Singapore Statis News 9:1-4 no 1 '86 Prepared by the Child Care Branch, Ministry of Community Development.

$†$ Kahn, Alfred J. and Sheila B. Kamerman. Child care: facing the hard choices. $87 \mathrm{xi}+273 \mathrm{p}$ tables index (LC 86-28710) (ISBN 0.86509-164-9) \$26-Auburn House Major demographic and social developments; the Reagan administration's emphasis on privatization; pros and cons of local and state initiatives; policy options.

Landers, Robert K. New deal for the family. bibl il chart Editoral Research Repts p 551-68 Jl 25 '86

Contents: Juggling motherhood and jobs; Feminists reconsider aims; Pro-family politics.

issue of maternity leave; day care policies; U.S.

Schwenk, Frankie D.-Child-care arrangements and

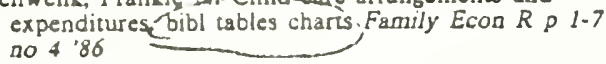

United States.

\section{DEAD BODIES (LAW)}

\footnotetext{
Andrews, Lori B. My body, my property. Hastings Center Rept 16:28-38 O '86

Whether patients (or their heirs) should be allowed to share in the profits derived from research conducted on the body parts and products of the patient; the issue of informed consent.
}

\section{DEALER RELATIONS}

